\title{
The neotype of Retepora nodulosa Phillips, 1836
}

SIR - In an earlier paper (Tavener-Smith, 1965) revising the Carboniferous bryozoan Retepora nodulosa Phillips, 1836, the species was referred to the genus Minilya Crockford and a neotype specimen (British Museum (Natural History) PD4495) was chosen. However, Phillips gave the collecting localities for his species as Whitewell in Bolland, Greenhow Hill and Harrogate, whereas the neotype was collected from Carrick Lough in County Fermanagh, Northern Ireland. Therefore, this specimen has no validity as a neotype because it contravenes Article $75 \mathrm{c}(5)$ of the International Code of Zoological Nomenclature which specifies that a neotype is validly designated only when it is published with evidence that it came as nearly as practicable from the original type-locality.

As Phillip's type material of $R$. nodulosa is still believed to be lost (it is not recognizable among his specimens at the Oxford University Museum), a second specimen of $R$. nodulosa has been collected from a Viséan locality $275 \mathrm{~m}$ NW of Duck Street Farm, Greenhow Hill, and is here designated as the neotype of the species to replace the Carrick Lough specimen. This proposed neotype PD5339 is a colony fragment, about $10 \mathrm{~mm} \times 15 \mathrm{~mm}$, attached to a large piece of limestone and showing the characteristic hour-glass fenestrule shape evident in Phillip's original figures of $R$. nodulosa. It is adequately distinguished from similar fenestellids by the description given previously (Tavener-Smith, 1965).

\section{References}

Phillips, J. 1836. Illustrations of the Geology of Yorkshire. Part II. London. Tavener-Smith, R. 1965. A revision of Retepora nodulosa Phillips, 1836. Geol. Mag. 102, 135-42.

Department of Geology

R. TAVENER-SMITH

University of Natal,

Durban,

South Africa

23rd January 1981

Geol. Mag. 118 (5), 1981, p. 565. Printed in Great Britain. 